TRANS EXPLOITS 
Anima Critical Race Studies Otherwise

A series edited by Mel Y. Chen and Jasbir K. Puar 


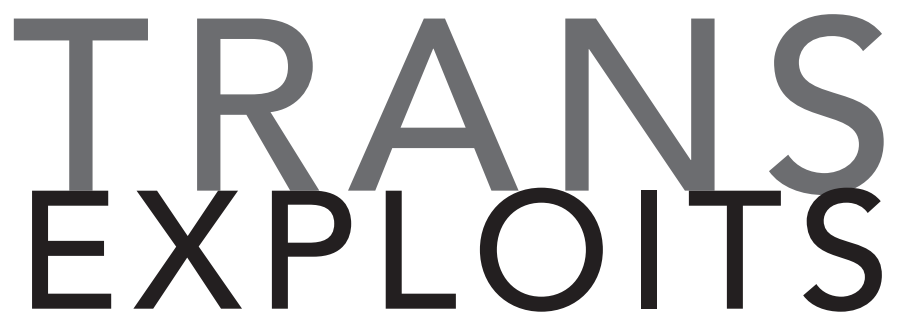

Trans of Color Cultures and Technologies in Movement

JIAN NEO CHEN 
(C) 2019 Duke University Press

All rights reserved

Printed in the United States of America on acid-free paper $\infty$

Designed by Courtney Leigh Baker

Typeset in Whitman and Avenir by Copperline Book Services

Library of Congress Cataloging-in-Publication Data

Names: Chen, Jian Neo, [date] author.

Title: Trans exploits : trans of color cultures and technologies

in movement / Jian Neo Chen.

Description: Durham : Duke University Press, 2019.

Series: Anima / a series edited by Mel Y. Chen and Jasbir K. Puar |

Includes bibliographical references and index.

Identifiers: LCCN 2018008215 (print) | LCCN 2018009564 (ebook)

ISBN 9781478002338 (ebook)

ISBN 9781478000662 (hardcover : alk. paper)

ISBN 9781478000877 (pbk. : alk. paper)

Subjects: LCSH: Transgender people. | Minorities. | Transgender artists. | Minority artists. | Transgender people-Political activity. |

Minorities-Political activity.

Classification: LCC HQ77.9 (ebook) | LCC HQ77.9 .C44 2018 (print) |

$$
\text { DDC 306.76/8-dc23 }
$$

LC record available at https://lccn.loc.gov/20180o8215

Cover art: Yozmit, Sound of New Pussy music video, 2012. Image design by Yvette Choy. Courtesy of Yozmit. 


\section{For kindreds}


This page intentionally left blank 